Article

\title{
Green Initiatives Adoption and Environmental Performance of Public Listed Companies in Malaysia
}

\author{
Nor Azah Abdul Aziz ${ }^{1}$, Tze San Ong ${ }^{2, *(1)}$, Soon Yau Foong ${ }^{3}$, Rosmila Senik ${ }^{2}$ \\ and Hassan Attan ${ }^{4}$ \\ 1 Faculty of Technology Management and Technopreneurship, Universiti Teknikal Malaysia Melaka, \\ Hang Tuah Jaya, Durian Tunggal 76100, Malaysia; azahaziz@utem.edu.my \\ 2 Faculty of Economics and Management, Universiti Putra Malaysia, Serdang 43400, Malaysia; \\ rosmilasenik@upm.edu.my \\ 3 Putra Business School, Universiti Putra Malaysia, Serdang 43400, Malaysia; syfoong@putrabs.edu.my \\ 4 Faculty of Engineering Technology, Universiti Teknikal Malaysia Melaka, Hang Tuah Jaya, \\ Durian Tunggal 76100, Malaysia; hassan@utem.edu.my \\ * Correspondence: tzesan1108@gmail.com or tzesan@upm.edu.my
}

Received: 6 March 2018; Accepted: 23 May 2018; Published: 14 June 2018

check for updates

\begin{abstract}
Environmental issues bring about thoughtful questions on the roles of business organisations in society. Irrespective of whether they are contributing to a better environment or worsening it, organisations have to acknowledge environmental or green issues through impact research and measurement. This article aims to examine the extent of green initiatives adoption and its impact on environmental performance of public listed companies (PLCs) in Malaysia. A questionnaire survey was conducted on PLCs and data from 120 samples were analysed using a statistical tool partial least square-structural equation modelling (PLS-SEM). Interviews were also conducted with a few selected companies to obtain in-depth information on green practices and to support the survey findings. The findings reveal that the extent of green initiatives adoption and environmental performance is at moderate level. Green initiatives adoption positively affects the environmental performance of Malaysian PLCs. The present study contributes to the literature of environmental management in the context of green and sustainable development. It also provides some important contributions for management practices by providing empirical evidence to managers that green initiatives should be extensively adopted to enhance environmental performances.
\end{abstract}

Keywords: green initiatives adoption; environmental performance; public listed companies; Malaysia

\section{Introduction}

Concerns on environmental issues have triggered environmental sustainability practices among business organisations. In Malaysia, environmental issues include pollutions from use of fertilizers, pesticides, and herbicides, and gaseous emissions of industrial processes. Air pollution is contributed largely by emission of motor vehicles and opens burning of industrial waste, mainly by wood-based and rubber-based factories. Water pollution results from the spoliation of land caused by activities such as tin mining and deforestation, and from domestic wastes [1].

Malaysian government has been seriously emphasising environmental preservation through various initiatives such as promoting and financing high impact research on green technologies by the Ministry of Energy, Green Technology, and Water (KeTTHA) in 2009 [2]. Sustainability has always been promoted by Bursa Malaysia as a key to success in business today. For this aim, the Malaysian government and Bursa Malaysia have mandated all public listed companies (PLCs) produce a sustainability report, called the corporate social responsibility (CSR) report, to reflect sustainability 
practices [3]. Environmental or green practices require conducting activities in ways that could enrich the environment rather than harm it [4]. Past studies indicated that green initiatives enable the intended green strategies to be successfully executed towards facilitating a better organisational performance [5]. Organisations that adopted green initiatives by adjusting their activities consequently improved their organisational performance [6].

Therefore, the aim of this study was to examine the extent of green initiative adoption in Malaysian PLCs and its impact on environmental performance. This needs to be examined empirically in the Malaysian context for the sustainability agenda to be realized.

\section{Literature Review}

\subsection{Adoption of Green Initiatives}

Previous studies highlighted some green initiatives in companies. The green initiatives adopted include: green supply chain management that consists of waste management, green packaging, evaluating vendors on their green performance, reducing carbon emissions in the delivery of goods, and developing more eco-friendly products [7]; green logistic of truck fleets [8]; corporate environmental management [9]; energy saving [10]; green strategies and green marketing [11]; and environmental attitude [12]. In East Asia, [13] revealed that businesses, investors, and insurers are implementing better quantitative assessments to reduce climate risks. The assessments are incorporated in their daily operations and also for long-term investment decisions. They also put effort into developing international guidelines, common policies, legal frameworks, setting targets, pricing policies, and other mechanisms to reduce climate risks to support better climate risk management, assessments and reporting.

In Malaysia, among the green initiatives adopted is energy saving. Low energy office (LEO) building enjoins the energy efficient features through an integrated building design process and computer simulation, and becomes the first government LEO building. LEO building saves up to $50 \%$ of energy compared to buildings without energy efficient features. Energy efficient buildings in Malaysia are buildings with solar building-integrated photovoltaic (BIPV) that have set a new standard for sustainable buildings in Malaysia and the ASEAN region. The Malaysian government has been seriously emphasising environmental preservation through various initiatives; for example, the Malaysia Development Plan and Vision 2020 is targeting for the country to become a developed nation and focuses on the aspect of environmental sustainability [14]. In addition, ethical or social responsibility investment funds were launched in 2004 [15]. Promotion and financing of high impact research on green technologies by the Ministry of Energy, Green Technology, and Water (KeTTHA) were done in April 2009 [2]. Malaysia, being part of the global economic network, has to respond to the global trend of environmental preservation to gain access to global markets. Hence, in 2007, regulations were introduced to mandate all public listed companies (PLCs) in Malaysia to produce a corporate social responsibility (CSR) report that comprises social and environmental reporting [3]. These reflect the concern over green initiatives by the Malaysian government with an expectation of a strong environmental commitment by organisations in Malaysia. Waste management, recycling, energy saving, environmental or health and safety measures, process redesign for environmental or health and safety, green supply chain, paperless business and tree planting might be among the green initiatives adopted by organisations these days.

Moreover, [16] studied the green practices among ISO 14001 certified firms in Malaysia. The green practiced by the firms were eco design, green purchasing, and reverse logistic. Eco design consists of: (1) design for reduction or elimination of environmentally hazardous materials; (2) design for reuse with or without minimal treatment of the used product; (3) design for recycling; (4) design for remanufacturing; and (5) design for resource efficiency. Green purchasing consists of: (1) product content requirements; (2) product content restrictions; (3) product content labelling; (4) supplier questionnaires; (5) supplier environmental management systems; (6) supplier certification; and (7) 
supplier compliance auditing. Reverse logistic consists of: (1) reuse; (2) remanufacturing; and (3) recycling.

\subsection{Environmental Performance}

In the accounting literature, environmental performance has been investigated in terms of environmental impacts caused by business conduct, such as hazardous recycled wastes [17], toxic releases [18], pollution in discharged water [19], and non-compliance acts against environmental laws [20]. The environmental impacts are used as a representative for environmental performance and cover various aspects. As reported by [21], according to organisational theorists, environmental performance could be divided into two main dimensions: results and process. The outcome dimension is measured in terms of the accomplishment of goals [22].

A goal model is often reflected by focusing on the ending, such as the achievement of financial and environmental goals, objectives, targets, etc. Generally, the environmental impacts refer to these dimensions in past studies. On the other hand, the process dimension is based on a system model. While not neglecting the importance of the outcomes, the process dimension emphasises the means needed for the achievement of specific goals [23]. Thus, environmental performance also denotes the process and product improvement affecting by the integration of environmental considerations into the operational decisions of firms [24]. A study by [25] on EMA adoption indicated that there is a significantly positive correlation between EMA adoption level and environmental performance, such as reduction in the use of water, energy, and solid waste. This means that, in any organisation, a positive relationship also exists between the green integration into MCS and environmental performance.

\section{Conceptual Framework and Hypothesis Development}

Figure 1 illustrates the conceptual framework of this study which consists of green initiative adoption and environmental performance.

Institutional theories through coercive and normative pressure drive companies to adopt green practises [7]. Contingency theory explains that, in response to challenging green issues, many organisations have started to adopt green practises, resulting in improved firm performance [26]. Stakeholder theory also explains that actions undertaken in the best interests of stakeholders would lead to positive firm performance [27] and the survival of organisations in the long run [28]. This brings us to the hypothesis for this study i.e. adoption of green initiatives positively affects environmental performance. 
Green Initiatives Adoption

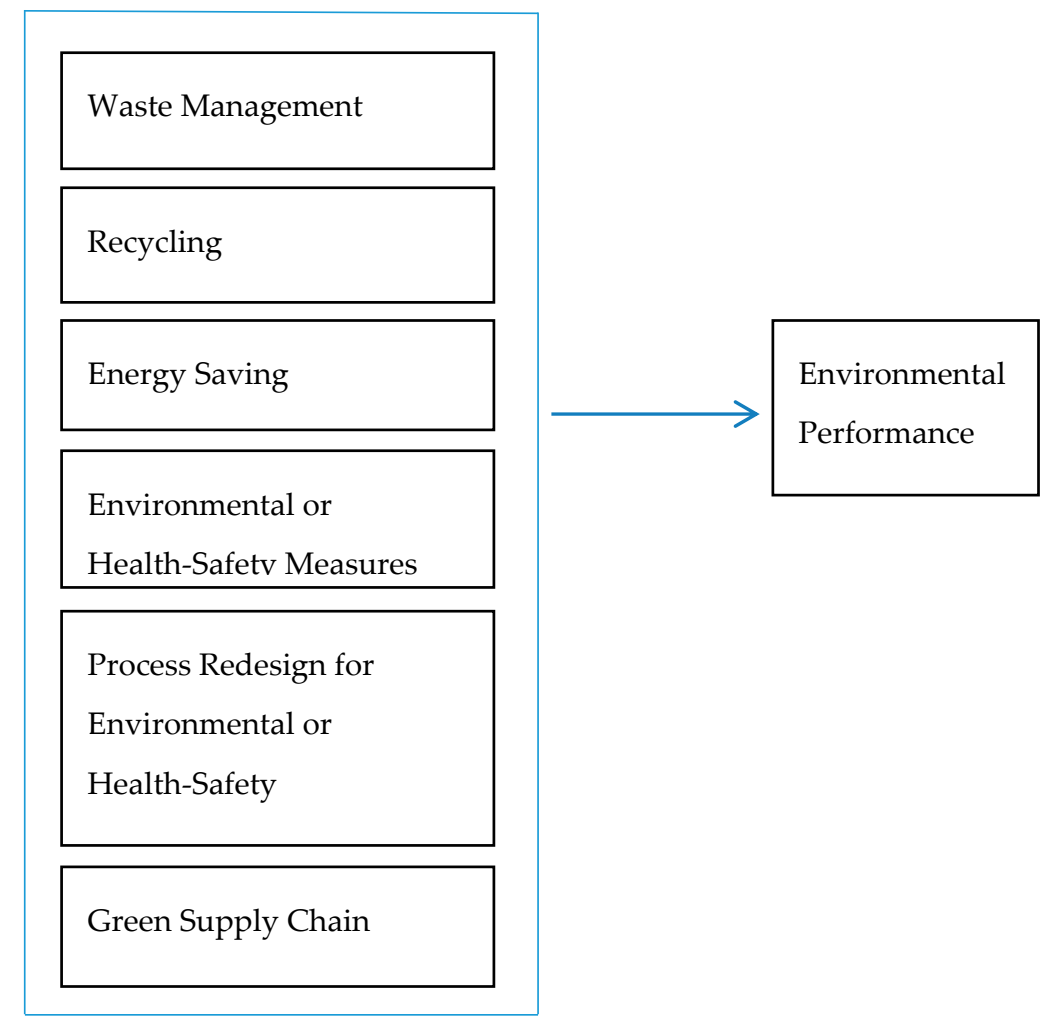

Figure 1. Conceptual Framework.

\section{Methodology}

\subsection{Research Design}

The population frame was the list of public companies quoted on Bursa Malaysia and the unit of analysis was at the organisational level. PLCs in Malaysia have been mandated to produce CSR reports since 2007, which suggests a high possibility that these companies have adopted some green initiatives. This study was a cross-sectional research using questionnaire survey with the selection of respondents inclusive of organisational top management such as chief executive officer, managing director, financial controller, and senior manager. Data were collected using questionnaire survey distributed to all PLCs on Bursa Malaysia in May 2015. A structured questionnaire was developed and used for data collection. The questionnaire items were adapted from previous relevant and related literature. However, some alterations were made to fit the present study's objectives. Data were entered into Statistical Package for the Social Science (SPSS) as a preparation before further analysing the data using partial least square-structural equation modelling (PLS-SEM). PLS-SEM according to [29] was used to check the reliability and validity of items and constructs, correlation values, multiple regression analysis, and the significance of the hypothesised relationships. PLS-SEM is a kind of SEM that is used to test a series of hypothesized models due to its ability to simultaneously test more complex path models involving a larger number of variables. There are two types of SEM, namely Covariance-Based SEM (CB-SEM) and Variance-Based SEM (PLS-SEM), whereby CB-SEM is used to confirm (or reject) theories and PLS-SEM is primarily used to develop theories. PLS-SEM is used when sample sizes are small, and the data are not necessarily normal. In situations where theory is less developed, researchers should consider the use of PLS-SEM as an alternative approach to CB-SEM. This is particularly true if the primary objective of applying structural modelling is prediction and explanation of target constructs. PLS-SEM can also handle a single item in the structural model. Hence, PLS-SEM is relevant for this study. To provide further insight into the findings of the questionnaire survey, in-depth interviews were conducted with 
selected respondents. The purpose of the interviews was to complement and support the quantitative findings [30].

\subsection{Measurement of Constructs}

In the present study, green initiative adoption is adapted from Sustainable Development Initiatives in Malaysia by Malaysia Productivity Corporation, 2010. The waste management practice includes reduce waste and packaging, transportation, collection, disposal, treatment, and monitoring and regulating. It is aimed to lessen unfavourable impacts of waste on environment and health. A simple example of waste management is to provide bin to store waste. For recycling practice, it consists of processing used materials into new products to reduce the usage of new raw materials, energy and water, which can reduce air and water pollutions, for example recycling of polythene products and cans before transforming them into new materials without the need to send the whole waste to landfills or dump sites. Another example is, by collecting waste paper, and sorting and grading them accordingly, before selling them to paper mills that would recycle and convert them into various types of industrial paper. Energy saving practice usually includes the adoption of greenhouse gas (GHG) emission reduction programs at premises or factories to reduce GHG emissions, the use of light-emitting diodes (LED) bulb to reduce carbon dioxide emission and reduce energy usage. Energy saving practice includes the increase of energy efficiency in machineries and equipment usage such as high efficiency motor and pumps, the integration of renewable energy system and energy saving features in buildings, and the increased usage of thermal insulation for roofs in air conditioned buildings. Environmental or health and safety measures normally consist of prevention of harmful substances entering products, processes, work areas, and environment. Examples include measures addressing ergonomics and air quality, and minimising the usage of hazardous chemicals and gases. In addition, process redesign for environmental and health and safety includes recreating or remodelling of products for better energy saving and being more environmental friendly. Examples include: (i) front-load technology of washing machines can reduce water consumption up to 70\%; (ii) intelligent inverter technology can reduce the consumption of electricity, for example, refrigerator uses $40 \%$ less electricity or exact amount of electricity needed; and (iii) intelligent inverter technology, precise power adjustment and compressor in air conditioner can save up to $60 \%$ energy saving and can cut carbon dioxide emission. Moreover, green supply chain initiatives include offering inventory management services for suppliers and clients, cleaner production, green packaging, design of products for reuse and recycling, return packaging to suppliers for reuse or recycling, cooperation with customers for eco-design, and using less energy during product transportation. Hence, green practices are environmentally-friendly activities and going green implies pursuing knowledge, activities, and lifestyles that lead to better environmental well-being.

Environmental performance measures were adopted from [25], namely reduction in pollution emissions; reduction in use of water; reduction in use of energy; reduction in use of toxic inputs; reduction in use of paper; reduction of noise; reduction of smell/odour emissions; and reduction in the risk of severe accidents.

\subsection{Test of Response Bias}

The present study used $t$-test to test for the non-response bias suggested by Oppenheim (2001). The sample was divided into two, namely "early responses" for companies that returned their questionnaires within two weeks after the date of distribution, and "late responses" for companies that returned their questionnaires after two weeks from the date of distribution, after many follow-up attempts [31]. Accordingly, early responses were represented by the first thirty responses, and late responses were represented by the last thirty responses. An independent $t$-test was employed to determine the significant difference between early responses and late responses for all variables examined in this study. $t$-test shows that the $p$-value of the variables are above 0.05 . Hence, there is no significant difference of the mean score of these variables between early response and late response. 
In general, there is no significant difference found in all variables. This suggests that non-response bias is not an issue in this study. The result is illustrated in Tables 1 and 2.

Table 1. Group Statistics.

\begin{tabular}{lcllll}
\hline \multirow{2}{*}{ GREEN-ADOPT } & Early Respondent & 30 & 3.57222 & 0.788669 & 0.143991 \\
& Late Respondent & 30 & 3.58333 & 0.660532 & 0.120596 \\
\hline \multirow{2}{*}{ PERFORMANCE } & Early Respondent & 30 & 3.30639 & 0.676124 & 0.123443 \\
& Late Respondent & 30 & 3.58500 & 0.464457 & 0.084798 \\
\hline
\end{tabular}

Table 2. Independent Samples Test.

\begin{tabular}{|c|c|c|c|c|c|c|c|c|c|c|}
\hline & & \multicolumn{2}{|c|}{$\begin{array}{l}\text { Levene's Test for } \\
\text { Equality of Variances }\end{array}$} & \multicolumn{7}{|c|}{$t$-Test for Equality of Means } \\
\hline & & \multirow[t]{2}{*}{$\mathbf{F}$} & \multirow{2}{*}{ Sig. } & \multirow[t]{2}{*}{$\mathbf{t}$} & \multirow{2}{*}{ df } & \multirow{2}{*}{ Sig. (2-tailed) } & \multirow{2}{*}{$\begin{array}{c}\text { Mean } \\
\text { Difference }\end{array}$} & \multirow{2}{*}{$\begin{array}{l}\text { Std. Error } \\
\text { Difference }\end{array}$} & \multicolumn{2}{|c|}{$\begin{array}{c}95 \% \text { Confidence Interval } \\
\text { of the Difference }\end{array}$} \\
\hline & & & & & & & & & Lower & Upper \\
\hline \multirow[t]{2}{*}{ GREEN-ADOPT } & $\begin{array}{l}\text { Equal variances } \\
\text { assumed }\end{array}$ & 0.843 & 0.362 & -0.059 & 58 & 0.953 & -0.011111 & 0.187821 & -0.387076 & 0.364853 \\
\hline & $\begin{array}{l}\text { Equal variances } \\
\text { not assumed }\end{array}$ & & & -0.059 & 56.268 & 0.953 & -0.011111 & 0.187821 & -0.387322 & 0.365100 \\
\hline \multirow[t]{2}{*}{ PERFORMANCE } & $\begin{array}{c}\text { Equal variances } \\
\text { assumed }\end{array}$ & 2.110 & 0.152 & -1.860 & 58 & 0.068 & -0.278611 & 0.149763 & -0.578393 & 0.021171 \\
\hline & $\begin{array}{l}\text { Equal variances } \\
\text { not assumed }\end{array}$ & & & -1.860 & 51.385 & 0.069 & -0.278611 & 0.149763 & -0.579217 & 0.021995 \\
\hline
\end{tabular}

\section{Analysis and Results}

Table 3 shows that $78.4 \%$ of the sample companies have been adopting green practices for more than four years, and all of them adopted green practices in one form or another. The highest percentage of companies comes from "Trade and Services Sector" (25\%).

Table 3. Profile of Sample Companies.

\begin{tabular}{ccc}
\hline Type & Frequency & Percentage (\%) \\
\hline Duration of Green Practice Adoption & & \\
1-3 Years & 26 & 21.7 \\
4-10 Years & 62 & 51.7 \\
>10 Years & 32 & 26.7 \\
Total & 120 & 100.0 \\
Industrial Sector & & \\
Consumer Products & 23 & 19.2 \\
Industrial Products & 22 & 18.3 \\
Construction & 8 & 6.7 \\
Trade and Services & 30 & 25.0 \\
Finance & 15 & 12.5 \\
Properties & 3 & 2.5 \\
Mining & 2 & 1.7 \\
Plantation & 7 & 5.8 \\
Technology & 10 & 8.3 \\
Total & 120 & 100.0 \\
\hline
\end{tabular}

Table 4 shows about two-third of the respondents $(68.3 \%)$ are male and $89.2 \%$ are aged $>30$ years. Almost all of the respondents (93.3\%) obtained certificates of tertiary education, either having a first degree or a professional degree, and they held top or senior managerial positions. Next, $85.8 \%$ have more than four years of working experience in their current companies and $58.3 \%$ of the respondents have more than ten years working experience in their current companies, suggesting that most respondents were knowledgeable about their companies and well experienced in operational practices. 
Table 4. Profile of Respondents.

\begin{tabular}{lcc}
\hline \multicolumn{1}{c}{ Type } & Frequency & Percentage (\%) \\
\hline Gender & & \\
Male & 82 & 68.3 \\
Female & 38 & 31.7 \\
Total & 120 & 100.0 \\
\hline Age & & \\
$<30$ Years & 13 & 10.8 \\
31-50 Years & 79 & 65.8 \\
$>$ 50 Years & 28 & 23.3 \\
Total & 120 & 100.0 \\
\hline Education & & \\
Professional & 47 & 39.2 \\
Tertiary & 65 & 54.2 \\
Others & 8 & 6.7 \\
Total & 120 & 100.0 \\
\hline Position & & \\
Chief Executive Officer & 20 & 16.7 \\
Financial Controller/Senior Accountant & 10 & 8.3 \\
Senior/General Manager & 63 & 52.5 \\
Other Top-level Managers & 27 & 22.5 \\
Total & 120 & 100.0 \\
\hline Working Experience in Current & & \\
Company & 120 & 14.2 \\
1-3 Years & & \\
4-10 Years & 33 & 58.3 \\
Above 10 Years & 70.0 \\
Total & & \\
\hline
\end{tabular}

Table 5 shows that the extent of green initiative adoption and environmental performance is at moderate level.

Table 5. Descriptive statistics for the Constructs and Items.

\begin{tabular}{cccc}
\hline Construct and Items & Mean & Construct and Items & Mean \\
\hline Extent of Green Initiative Adoption & 3.764 & Environmental Performance & 3.292 \\
B01. Waste management & 3.792 & D01. Reduction in pollutant emissions & 3.292 \\
B02. Recycling & 3.950 & D02. Reduction in use of waste & 3.292 \\
B03. Energy saving & 4.008 & D03. Reduction in use of energy & 3.400 \\
B04. Environmental or health and safety measures & 4.075 & D04. Reduction in use of toxic inputs & 3.225 \\
B05. Process redesign for environmental and & 3.558 & D06. Reduction in noise & 3.033 \\
health and safety & 3.200 & D07. Reduction of smell/odour emissions & 3.108 \\
B06. Green supply chain & & D08. Reduction in the risk of severe accidents & 3.617 \\
\hline
\end{tabular}

Scale: $1=$ none and $5=$ extensive

Figure 2 shows the statistical model for the study. 


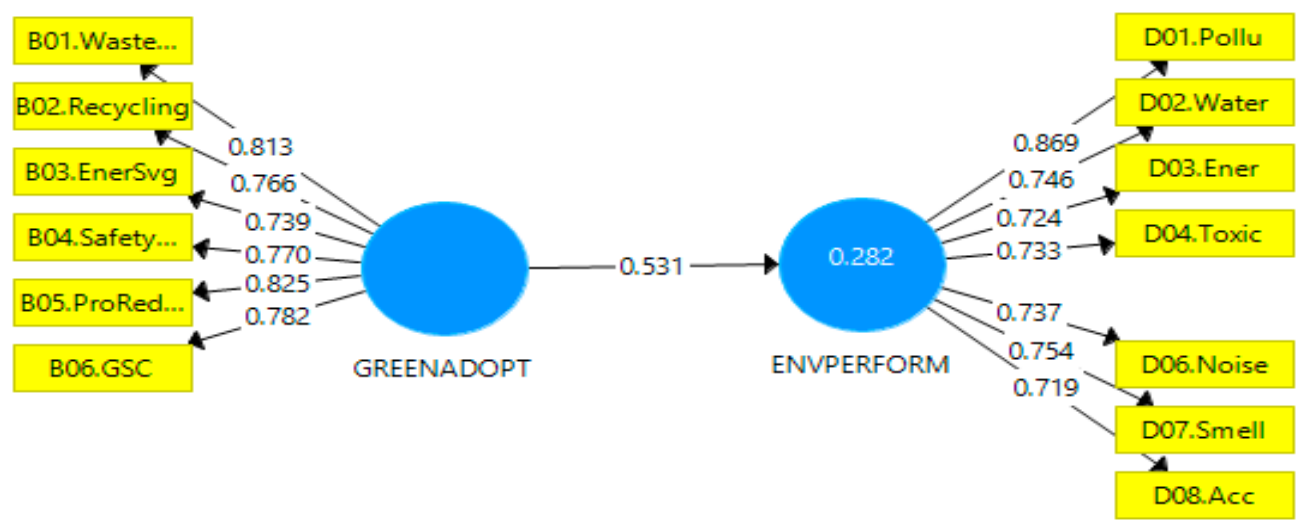

Figure 2. Statistical Model of Study.

The results of statistical analysis are shown in Tables 6 and 7.

Table 6. Summary of Measurement Model.

\begin{tabular}{cccccc}
\hline Latent Variable & Indicators & Loadings & Composite Reliability & AVE & Discriminant Analysis \\
\hline \multirow{2}{*}{ GREEN-ADOPT } & & $>0.70$ & $>0.70$ & $>0.5$ & \\
& B01 & 0.813 & 0.905 & 0.614 & Yes \\
& B02 & 0.766 & & & \\
B03 & 0.739 & & & \\
& B04 & 0.770 & & & Yes \\
ENVPERFORM & B05 & 0.825 & & & \\
& B06 & 0.782 & 0.572 & \\
& D01 & 0.869 & 0.903 & & \\
& D02 & 0.746 & & & \\
& D03 & 0.724 & & & \\
& D04 & 0.733 & & & \\
& D06 & 0.737 & & & \\
& D07 & 0.754 & & & \\
& D08 & 0.719 & & & \\
\end{tabular}

Table 7. Summary of Structural Model.

\begin{tabular}{|c|c|c|c|c|c|c|c|}
\hline Path Coefficient & $\mathrm{VIF}<5$ & $\begin{array}{c}\text { T Statistics } \\
>1.96 \text { or }>1.645\end{array}$ & $p$ Values $<0.05$ & Path Coefficient & $\mathbf{R}^{2}$ & Effect Size-f $f^{2}$ & $\begin{array}{c}\text { Predictive } \\
\text { Relevance-( }{ }^{2}\end{array}$ \\
\hline $\begin{array}{l}\text { GA->PERF } \\
\text { PERFORM }\end{array}$ & 1 & 10.538 & 0.000 & 0.531 & 0.282 & 0.393 & 0.120 \\
\hline
\end{tabular}

GA = Green Adoption; PERFOR = Performance .

\subsection{Internal Consistency}

Internal consistency was measured using "composite reliability (CR)". Internal consistency reliability defines the consistency of the results delivered in a test to ensure that the various items measured different constructs and delivered consistent scores. The $C R$ value should be $>0.70$ because $<0.60$ shows lack of internal consistency reliability, $0.60-0.70$ is acceptable in exploratory research and $0.70-0.90$ is satisfactory [32]. In this study, all indicators have CR $>0.70$, hence have a satisfactory internal consistency reliability.

\subsection{Indicator Reliability}

In determining "Preacher and Hayes indicator reliability", which is an indicator to measure whether an item is a member of the construct, the loadings to the respective constructs were computed [33]. The standardised loadings should be $>0.70$. The common rule of thumb is outer loadings should be $>0.70$ because the squared outer loading is equivalent to the communality (at least 
0.5 or $50 \%$ ). In this study, there were two item loadings below the acceptable value and hence were removed. The items were "paperless $=0.626$ " and "tree planting $=0.670$ ". The inclusion of these items would negatively affect the later measurement and structural model. Researchers should carefully examine the effect of removing an item. Outer loading between 0.40 and 0.70 should be considered for removal from the scale only when deleting the indicator leads to an increase in the composite reliability or the average variance extracted (AVE). In addition, the removal would not affect content validity, but an item $<0.40$ should be eliminated. The results show outer loadings after removing "paperless $=0.626$ " and "tree planting $=0.670$ ".

\subsection{Convergent Validity}

Convergent Validity is the extent to which a measure correlates positively with the alternative measures of the same construct. The items share a high proportion of variance. To establish convergent validity, the outer loadings of the indicators and Average Variance Extracted (AVE) should be considered. AVE is defined as the grand mean value of the squared loadings and equivalent to the communality of a construct. The outer loading of the indicators should be $>0.7$ and AVE should be $>0.5$. AVE $<0.5$ indicates that, on average, more errors remain in the items than the variance explained by the construct. In this study, the results show that AVE for all constructs were $>0.5$. As all constructs had AVE $>0.5$ and item outer loadings $>0.70$, the items shared a high proportion of variance and a measure positively correlated with the alternative measures of the same construct.

\subsection{Discriminant Validity}

Discriminant Validity is the extent to which a construct is truly distinct from other constructs by empirical standards. To determine if the items loaded on the other constructs equally as well as on their theorised construct, cross loadings, Fornell-Larcker criterion, and heterotrait-monotrait ratio of correlations (HTMT) were computed. For "cross loadings", the outer loading on associated constructs should be greater than all of its loadings on other constructs. For "Fornell-Larcker criterion", the square root of AVE should be greater than the latent variable correlations. For HTMT, the value of inter-correlation between construct and construct should be $<0.85$ or $<0.90$. If one of the assessments meets the criteria, then the constructs do not share same concept and they are discriminant. In this study, the assessment values met the criteria of cross loadings, Fornell-Larcker, and HTMT. Hence, the constructs did not share the same concept and they were discriminant.

Table 6 indicates that all items and constructs are reliable and valid after taking out item "DO5. Reduction in use of paper". This item did not measure the construct it was designed to measure, as its factor loading was $<0.70$ and affected the whole measurement model.

\subsection{Collinearity Issues}

Collinearity indicates that the predictor (independent) variables might be highly inter-correlated. The path coefficient might be biased if the estimation involves significant levels of collinearity among the predictor constructs. Variance Inflation Factor (VIF) was used to test for collinearity. VIF $>5$ in the predictor constructs indicates that collinearity is too high. If collinearity exceeds the threshold, researchers should consider eliminating constructs, merging predictors into a single construct, or creating higher-order constructs to deal with collinearity problems. The results indicated that all of the VIF were $<5$ and, hence, no collinearity exists.

\subsection{Significance}

The test for significance of the structural model relationships, Bootstrapping-Path coefficient, was used based on T Statistics $>1.96$ for two-tailed test; T Statistics $>1.645$ for one-tailed test; and $p$ value $<0.05$ for significance. The results indicated the path was statistically significant $($ GREENADOPT $\rightarrow$ ENVPERFORM), which has $p=0.000(>0.05)$, and T Statistics $=10.538(<1.645)$. 


\subsection{Relevance}

To test for the relevance of significant relationship, PLS algorithm coefficient was used. The results show the relative importance of the exogenous (independent) constructs in predicting the endogenous (dependent) constructs. Green Adoption (GREENADOPT) $=0.531$ is the most important to Environmental Performance (ENVPERFORM).

\subsection{Predictive Accuracy of Model}

The "coefficient of multiple determinations $\left(R^{2}\right)$ " is a measure for the model's predictive accuracy and is calculated as the squared correlation between a specific endogenous construct's actual and predicted values. It illustrates how well the data fit a statistical model or "goodness-of-fit". In general, a model fits the data well if the difference between the observed values and the model's predicted values are small and unbiased. The $R^{2}$ ranges from 0 to 1 and the higher the $R^{2}$, the better the model fits the data. There is no specific rule of thumb for $R^{2}$ value. $R^{2}$ value $0.75=$ substantial, $0.50=$ moderate and 0.25 = weak. The level of $R^{2}$ for ENVPERFORM $=0.282$ showed that the proposed model explains an acceptable amount of the variance of ENVPERFOM. This indicated that the model's predictive accuracy was acceptable, showing a considerable explanatory power of the model.

\subsection{Effect Size ( $\left.f^{2}\right)$}

The "effect size $\left(\mathrm{f}^{2}\right)^{\prime}$ " is a measure of the impact of a specific exogenous construct on an endogenous construct. The $\mathrm{f}^{2}$ effect size measures the change in the $\mathrm{R}^{2}$ value when a specific exogenous construct is omitted from the model. It is used to evaluate whether the omitted predictor construct has a substantive impact on the $R^{2}$ values of the endogenous construct(s). $f^{2}$ value $0.35=$ large, $0.15=$ medium, and $0.02=$ small. The results indicated that the green adoption $($ GREENADOPT) $=0.393$ has a large effect in producing the $\mathrm{R}^{2}$ for environmental performance (ENVPERFORM).

\subsection{Blindfolding and Predictive Relevance $\left(Q^{2}\right)$}

Next, "blindfolding and predictive relevance $\left(Q^{2}\right)$ " is an indicator of the model's predictive relevance. The $\mathrm{Q}^{2}$ measure applies a sample reuse technique that omits part of the data matrix and uses the model estimates to predict the omitted part. It accurately predicts the data points of the indicators in reflective measurement models of multi-item as well as single-item endogenous constructs. The $\mathrm{Q}^{2}$ value is calculated using the cross-validated redundancy, which uses the path model estimates for both the structural model and the measurement model. $\mathrm{Q}^{2}$ larger than zero for a specific reflective endogenous latent variable indicates the path model's predictive relevance for a particular construct. $\mathrm{Q}^{2}$ of zero or below indicates a lack of predictive relevance. The value of $\mathrm{Q}^{2}$ was considerably above zero, ENVPERFORM $=0.120$, thus providing support for the reputation model's predictive relevance.

In Table 7, the predictor construct is summarised as having no collinearity, and the path was statistically significant. The exogenous driver construct has importance in predicting the endogenous construct. The overall model's predictive accuracy was moderate, indicating a considerable explanatory power of the model, and the exogenous construct has a considerable impact on an endogenous construct. In addition, the endogenous latent variable provided support for the reputation of model's predictive relevance. Thus, the model has the capability to answer the research questions and hypothesis.

The findings reveal that the extent of green initiative adoption and environmental performance is at moderate level. Green initiative adoption positively affects the environmental performance of Malaysian PLCs; hence, the hypothesis was supported. The impact of green initiative adoption on environmental performance includes: reduction in pollutant emissions, reduction in use of waste, reduction in use of energy, reduction in use of toxic inputs, reduction in noise, reduction of smell/odour emissions, and reduction in the risk of severe accidents. 


\section{Discussion}

\subsection{Extent of Green Initiative Adoption}

The results of data analysis showed that the extent of green initiative adoption in Malaysian PLCs is rather modest. PLCs practise certain extent of waste management, recycling, energy saving, environmental or health and safety measures, process redesign for environmental and health and safety, and green supply chain but are not proactive. Based on findings from the in-depth interviews with the top management of Companies A, B and C, the extent of the adoption depends on the nature of industries, beliefs of the top level managers, employee responsibility, education received, culture and pressure from certain groups. Industries that require high level of clean and healthy environment which need to be regularly checked by Health Department, such as poultry industry, extensively adopt green initiatives. For example, in the present study, it was found that they systematically managed industrial wastes, otherwise, it would lead to diseases onto their products, employees, and surrounding communities.

Companies also do charitable activities, for example paper wastes were given for free to those in needs. For this kind of industry, the top managers support green activities, as well as encourage and reward staff adopting or practicing green initiatives. Normally, companies would consider new green technology if it would give some benefits at low cost. For some companies, going green is not a priority, but others do make it a priority because of their beliefs and awareness on CSR activities.

\subsection{Effect of Green Initiative Adoption on Environmental Performance}

Referring to the results of data analysis, the adoption of green initiatives significantly affected the environmental performance of Malaysian PLCs; hence, the hypothesis was supported. Adoption of waste management, recycling, energy saving, environmental or health and safety measures, redesign process for environmental and health and safety, and green supply chain positively affected the environmental performance of Malaysian PLCs. Green initiative adoption affects environmental performance in the reduction in pollutant emissions, reduction in use of waste, reduction in use of energy, reduction in use of toxic inputs, reduction in noise, reduction of smell/odour emissions, and reduction in the risk of severe accidents. The effect of green initiative adoption on environmental performance in this study is consistent with the studies by [7] on supply chain management in Chinese manufacturing enterprises.

Institutional theory claims that coercive and normative pressure push manufacturers to adopt green practises and would give positive effect to the firm performance. Government agencies are the obvious factor that influences the adoption of green practices by organisations through the enforcement of rules and regulations. For instance, to reduce pollution to the environment, organisations are required to use pollution control technologies and report their pollution emissions to indicate their impact on the environment. Their failure to do so might cause these organisations to face legal sanctions which affect the business progress adversely. Stakeholder theory explains that the actions undertaken in the best interests of the stakeholders would lead to positive firm performance and the survival of organisations in the long run [34].

\section{Conclusions}

The study suggests that Malaysia needs more advanced green technologies and more effective monitoring and enforcement of rules and regulations. Their other challenges include the lack of green awareness, lack of financial incentives, and lack of technical resources. The adoption of green initiatives requires a lot of effort, time, and resources that are costly to the companies and might not yield returns in the short term. Green practices are also given less priority among Malaysian PLCs as they have to weigh the associated costs and profits because most business organisations are profit-oriented.

This study contributes to the literature of environmental management in the context of green and sustainable development, whereby it reveals that the extent of green initiative adoption in Malaysian 
PLCs is moderate in practice and contributes to the positive environmental performance. In addition, this study provides an analysis of the understanding of green practices and green management using survey approach. It is useful for this large-scale quantitative study as it allows the incorporation of a broader scope, on top of being supported by in-depth interviews with the top management of selected companies. This study delivers empirical evidence on how companies could contribute to meeting the needs of our planet and enhancing performance in their respective industries.

This study also provides some important contributions for management practices by providing empirical evidence to managers that green initiative adoption contributes to environmental performances to save the world. Companies should be more proactive and extensively adopt green initiatives to contribute to better environmental performance. The role of top managers in green initiatives is important because they are powerful in terms of nurturing companies to support proactive green strategies. Managers should encourage employees' involvement in green practices, perhaps rewarding them for their environmental improvement in their day-to-day activities. Managers should inform and train employees about environmental issues, environmental objectives, and environmental impacts of their actions on organisations. Moreover, regulatory authorities or policy makers could facilitate and encourage effective implementation of green initiatives by providing more incentives such as financial incentives, technical resources, governmental subsidies, tax incentives, training, pilot green projects, and green awareness. Governments should consider what elements of their existing work might contribute to sustainability, and how other elements of sustainability could interact and be incorporated for present and future positive impacts. Financial institutions should offer financing at lower rates for environmentally friendly technologies and lower the insurance premium to protect companies against environmental risks.

Limitations of the study are it only focused on the green initiative adoption in Malaysian PLCs, and the research findings were limited and too generic. Moreover, it only considered the institutional theory, contingency theory, and stakeholder theory. In terms of research methodology, as the research variables were measured through the perceptions of respondents, there were some rather subjective and leniency errors, where the observed scores had higher mean values due to over-emphasising the good performance or positive quality of the organisations. Furthermore, because of time and cost constraints, the data were only collected once, thus inheriting the usual limitations of cross-sectional data. This study also faced difficulty during data collection process as PLCs were mainly concerned and worried with the act of disclosing company's information and having lack of understanding on the importance of the research. According to [35], mail surveys in Malaysia normally have low response rate, ranging from $10 \%$ to $20 \%$.

Future research might be done in different countries on multiple types of organisations involving various green practices.

Author Contributions: Conceptualization, N.A.A.A. and S.Y.F.; Methodology, T.S.O.; Software, N.A.A.A. and T.S.O.; Validation, N.A.A.A., S.Y.F., T.S.O. and R.S.; Formal Analysis, N.A.A.A.; Investigation, N.A.A.A.; Resources, S.Y.F., T.S.O., R.S. and H.A.; Data Curation, N.A.A.A.; Writing-Original Draft Preparation, N.A.A.A.; Writing-Review and Editing, N.A.A.A., T.S.O., S.Y.F. and H.A.; Visualization, N.A.A.A.; Supervision, S.Y.F., T.S.O. and R.S.; Project Administration, N.A.A.A. and T.S.O.; Funding Acquisition, T.S.O.

Funding: This research was funded by Universiti Putra Malaysia and Universiti Teknikal Malaysia, Melaka.

Acknowledgments: The authors would like to thank the Universiti Putra Malaysia, Universiti Teknikal Malaysia Melaka and the Ministry of Education Malaysia for supporting this research project. The authors would also like to thank the Putra Business School (UPM) for facilitating this project. Many thanks are due to all the respondents who took part in the survey. Finally, the authors would like to thank the reviewers for their feedback.

Conflicts of Interest: The authors declare no conflict of interest.

\section{References}

1. Mokthsim, N.; Salleh, K. Malaysia's Efforts towards Achieving a Sustainable Development: Issues, Challenges and Prospects. Proceedia-Soc. Behav. Sci. 2014, 120, 299-307. [CrossRef] 
2. Department of Environment (DOE) Malaysia. Quaterly Report; Department of Environment: Putrajaya, Malaysia, 2010.

3. Zainal, D.; Zulkifli, N.; Saleh, Z. Corporate Social Responsibility Reporting in Malaysia: A Comparison Between Shariah and Non-Shariah Approved Firms. Middle East J. Sci. Res. 2013, 15, 1035-1046. [CrossRef]

4. Brundtland, G.H. Our Common Future; World Commission on Environment and Development: Brussels, Belgium, 1987.

5. Lisi, I.E. Translating environmental motivations into performance: The role of environmental performance measurement system. Manag. Account. Res. 2015, 29, 27-44. [CrossRef]

6. Henri, J.; Journeault, M. Eco-control: The influence of management control systems on environmental and economic performance. Account. Organ. Soc. 2010, 35, 63-80. [CrossRef]

7. Zhu, Q.; Sarkis, J.; Lai, K. Institutional-based antecedents and performance outcomes of internal and external green supply chain management practices. J. Purch. Supply Manag. 2013, 19, 106-117. [CrossRef]

8. Zhang, Y.; Thompson, R.G.; Bao, X.; Jiang, Y. Analyzing the promoting factors for adopting green logistics practices: A case study of road freight industry in Nanjing. Procedia Soc. Behav. Sci. 2014, 125, 432-444. [CrossRef]

9. Liu, X.; Liu, B.; Shishime, T.; Yu, Q.; Bi, J.; Fujitsuka, T. An empirical study on the driving mechanism of proactive corporate environmental management in China. J. Environ. Manag. 2010, 91, 1707-1717. [CrossRef] [PubMed]

10. Maarten, N.; Worrell, E.; Masanet, E. Energy Efficiency Improvement and Cost Saving Opportunities for the Petrochemical Industry - An Energy Star ${ }^{\circledR}$ Guide for Energy and Plant Managers; Lawrence Berkeley National Laboratory Permalink: Berkeley, CA, USA, 2008.

11. Chan, R.Y.K. Corporate environmentalism pursuit by foreign firms competing in China. J. World Bus. 2010, 45, 80-92. [CrossRef]

12. Magrini, A.; Lins, L.D.S. Integration between environmental management and strategic planning in the oil and gas sector. Energy Policy 2007, 35, 4869-4878. [CrossRef]

13. Barbier, E.B.; Burgess, J.C. Innovative corporate initiatives to reduce climate risk: Lesson from East Asia. Sustainability 2017, 10, 13. [CrossRef]

14. Mahyudin, N.; Rao, S.P. Integration of Environmental Sustainability Issues in the Teaching of Built Environment in Malaysian Universities. Presented at the First International Conference on Environment Research and Assessment, Bucharest, Romania, 23-27 March 2003.

15. Amran, A.; Devi, S.S. The impact of government and foreign affiliate influence on corporate social reporting: The case of Malaysia. Manag. Audit. J. 2008, 23, 386-404. [CrossRef]

16. Eltayeb, T.K.; Zailani, S.; Ramayah, T. Green supply chain initiatives among certified companies in Malaysia and environmental sustainability: Investigating the outcomes. Resour. Conserv. Recycl. 2011, 55, 495-506. [CrossRef]

17. Al-Tuwaijri, A.; Christensen, E.; Hughes, K.E. The relations among environmental disclosure, environmental performance and economic performance: A simultaneous equations approach. Account. Organ. Soc. 2004, 29, 447-471. [CrossRef]

18. Patten, D.M. The relation between environmental performance and environmental disclosure. Account. Organ. Soc. 2002, 27, 763-773. [CrossRef]

19. Cormier, D.; Magnan, M. Investors' assessment of implicit environmental liabilities: An empirical investigation. J. Account. Pub. Pol. 1997, 16, 215-241. [CrossRef]

20. Mobus, J.L. Mandatory Environmental Disclosures in a Legitimacy Theory Context. Account. Audit. Account. J. 2005, 18, 492-517. [CrossRef]

21. Henri, J.-F. Performance measurement and organizational effectiveness: Bridging the gap. Manag. Finance 2004, 30, 93-123. [CrossRef]

22. Etzioni, A. Two approaches to organizational analysis: A critique and suggestion. Adm. Sci. Q. 1960, 5, 257-278. [CrossRef]

23. Yuchtman, E.; Seashore, S.E. A system resource approach to organizational effectiveness. Am. Sociol. Rev. 1967, 32, 891-903. [CrossRef]

24. Melnyk, S.A.; Sroufe, R.P.; Calantone, R. Assessing the impact of environmental management systems on corporate and environmental performance. J. Oper. Manag. 2003, 21, 329-351. [CrossRef] 
25. Jalaludin, D.; Sulaiman, M.; Ahmad, N.; Nazli, N. Environmental management accounting: An empirical investigation of manufacturing companies in Malaysia. J. Asia-Pac. Cent. Environ. Account. 2010, 16, 31-45.

26. Henri, J.; Journeault, M. Eco-control: The influence of management control systems on environmental and organizational performance. Account. Organ. Soc. 2010, 35, 63-80. [CrossRef]

27. Deegan, C. Introduction-The Legitimising Effect of Social and Environmental Disclosures-A Theoretical Foundation. Account. Audit. Account. J. 2002, 15, 282-311. [CrossRef]

28. Phillips, R. Stakeholder Theory and Organisational Ethics; Berrett-Koehler Publishers, Inc: San Francisco, CA, USA, 2003.

29. Hair, J.F.; Hult, G.T.M.; Ringle, C.M.; Sarstedt, M.A. Primer on Partial Least Squares Structural Equation Modeling; Sage Publication Inc.: California, CA, USA, 2014.

30. Schramm, W. Instructional Television in Educational Reform: The Case of El Salvador; Institute for Communication Research: Stanford, CA, USA, 1971.

31. Lineback, J.F.; Thompson, K.J. Conducting Nonresponse Bias Analysis for Business Surveys. Office of Statistical Methods and Research for Economic Programs U.S. Census Bureau1, Washington, D.C. 20233 Section on Government Statistics-JSM 2010. Available online: https:/ /ww2.amstat.org/sections/srms / Proceedings/y2010/Files/306113_55883.pdf (accessed on 7 June 2018).

32. Nunnaly, J.C.; Bernstein, I.H. Psychometric Theory, 3rd ed.; McGraw-Hill: New York, NY, USA, 1994.

33. Preacher, K.J.; Hayes, A.F. Asymptotic and resampling strategies for assessing and comparing indirect effects in multiple mediator models. Behav. Res. Methods 2008, 40, 879-891. [CrossRef] [PubMed]

34. Phillips, R.; Freeman, R.E.; Wicks, A.C. What stakeholder theory is not. Bus. Ethics Q. 2003, 13, 479-502. [CrossRef]

35. Isa, C.R.; Foong, S.Y.; Sambasivan, M. The Roles of Market Competition and Advanced Manufacturing Technology in Predicting Management Accounting and Control Systems Change. Asia Pac. Manag. Rev. 2005, 10, 397-403.

(C) 2018 by the authors. Licensee MDPI, Basel, Switzerland. This article is an open access article distributed under the terms and conditions of the Creative Commons Attribution (CC BY) license (http:// creativecommons.org/licenses/by/4.0/). 